\title{
Akne Vulgaris Tedavisinde Oral Azitromisin ile Topikal Adapalen ve Oral Doksisiklin ile Topikal Adapalen Etkinliğinin ve Güvenirliğinin Karșılaștırılması ve bu Tedavilerin Yașam Kalitesi Üzerine Etkilerinin Ölçülmesi
}

\author{
Comparison of Safety and Efficacy of Oral Azithromycin-Topical \\ Adapalene Versus Oral Doxycycline-Topical Adapalene in the Treatment \\ of Acne Vulgaris and Determination of the Effects of These Treatments \\ on Patients' Quality of Life
}

Serap Kayhan, İlham Sabuncu, Zeynep Nurhan Saraçoğlu, Ayșe Esra Koku Aksu, Mustafa Tozun*

Eskișehir Osmangazi Üniversitesi Tıp Fakültesi, Deri ve Zührevi Hastalıklar Anabilim Dalı,

*Eskișehir Toplum Sağlığı Merkezi, Eskișehir, Türkiye

\section{Özet}

Amaç: Akne pilosebase ünitenin kronik inflamatuvar bir hastalı̆ııdır. Oral antibiyotikler ve topikal retinoidler akne tedavisinde etkilidir. Gereç ve Yöntemler: Bu çalıșmaya orta șiddetli akne vulgarisi olan 60 hasta alındı, hastalar randomize olarak iki gruba ayrıldı. Gruplar arasında yaș, cinsiyet ve akne șiddeti açısından farklılık yoktu. Birinci gruptaki hastalara azitromisin (500 mg haftada 3 gün), 2. gruptaki hastalara doksisiklin (100 mg/gün) tedavisi 12 hafta süre ile verildi. Sistemik tedaviye ek olarak her iki gruptaki hastaların tedavisine topikal adapalen jel eklendi. Klinik değerlendirme bașlangıçta ve 1, 2, 3. ayın sonunda yapıldı. Yan etkiler kaydedildi. Hastaların yașam kaliteleri Skindeks-29 ve Akne Yașam Kalite Ölçeği ile tedavi öncesi ve 3. ayın sonunda değerlendirildi.

Bulgular: Tedavi sonrasında her iki tedaviyi alan tüm hastalarda \%50'den fazla düzelme gözlendi. Azitromisin ile adapalen tedavisi alan 21 hastada ve doksisiklin ile adapalen tedavisi alan 23 hastada \%80 ve daha fazla düzelme gözlendi. Her iki tedavinin etkinlikleri karșılaștırıldığında lezyonların azalma yüzdesinde istatistiksel olarak anlamlı fark bulunamadı $(\mathrm{p}>0,05)$. Her iki tedavi yöntemi düsük yan etki insidansı ile güvenli bulundu. Skindeks-29 ve Akne Yașam Kalite Ölçeğinin skala skorlarında tedavi bașlangıcı ve tedavi sonrasında istatistiksel olarak anlamlı fark mevcuttu $(p<0,05)$. Yașam kalite ölçeklerinin skala skorları arasında iki grupta istatistiksel olarak anlamlı fark bulunamadı $(\mathrm{p}>0,05)$.

Sonuç: Her iki tedavi yöntemi etkili ve güvenli bulundu. Yașam kalite ölçeklerinde istatistiksel olarak anlamlı düzelme gözlendi. (Türkderm 2012; 46: 151-5)

Anahtar Kelimeler: Akne vulgaris, tedavi, yașam kalitesi

\section{Summary}

Background and Design: Acne vulgaris is a chronic inflammatory disease of the pilosebaceous unit. Oral antibiotics and topical retinoids are effective in the treatment of acne.

Materials and Methods: In this study, 60 patients with moderate acne vulgaris were evaluated; the patients were randomized into two equal groups. The groups were matched with respect to age, gender and clinical severity of acne. The patients in group 1 received oral azithromycin (500 mg daily on 3 consecutive days per week) and the patients in group 2 received doxycycline (100 mg daily) for 12 weeks. Topical adapalene gel was added to the systemic treatment in both groups. Clinical evaluation was performed at baseline and at the end of first, second and third months. Side effects were recorded. Quality of life in patients was measured with Skindex-29 and Acne Quality of Life Scale before treatment and at the end of third month.

Yazışma Adresi/Address for Correspondence: Dr. Ayșe Esra Koku, Eskișehir Osmangazi Üniversitesi Tip Fakültesi, Deri ve Zührevi Hastalkklar Anabilim Dalı, Eskișehir, Türkiye Tel.: +90 22223929 79/3550 E-posta: esraaksu@gmail.com Geliş Tarihi/Received: 12.04.2011 Kabul Tarihi/Accepted: 23.11.2011 
Results: At the end of the treatment, the patients in the two treatment groups had clinical improvement of more than $50 \%$. Twenty-one patients in the azithromycin-adapalene group and 23 patients in the doxycycline-adapelene group had more than $80 \%$ clinical improvement. There was not any statistically significant difference in the clinical efficacy between the two combinations. Both treatment regimens were safe with minimal side effects. There was statistically significant difference in Skindex-29 and Acne Quality of Life Scale scores at baseline and at the end of the treatment $(p<0.05)$. There was not any statistically significant difference in the mean scale scores of both quality life scales between the two groups $(p>0.05)$.

Conclusion: Both treatments were efficient and safe. There was significant improvement in quality of life scale scores in both groups. (Turkderm 2012; 46: 151-5) Key Words: Acne vulgaris, treatment, quality of life

\section{Giriş}

Akne vulgaris neredeyse tüm ergenlerde görülür ${ }^{1}$. Yaşamı tehdit eden ölümcül bir hastalık olmamakla birlikte, sebep olduğu kozmetik sorunlar nedeniyle yaş, cinsiyet ve hastalık şiddetinden bağımsız olarak hastalarda önemli fiziksel ve psikolojik rahatsızlıklara yol açabilir2.

Akne vulgaris tedavisi lezyonların tipine, yaygınlığına ve şiddetine göre değişiklik gösterir. Tedavinin belirlenmesinde aknenin yaşam kalitesi üzerine etkisi de ayrıca değerlendirilmelidir.

Orta şiddetli akne tedavisinde tipik olarak oral antibiyotik tedavisine ek olarak topikal retinoid tedavisi de önerilmektedir ${ }^{3}$. Bu çalışmada orta derecede akne vulgarisi olan hastaların tedavisinde oral azitromisin ile topikal adapalen jel ve oral doksisiklin ile topikal adapalen jelin etkinliklerinin ve güvenirliklerinin karşılaştırılması ve bu tedavilerin yaşam kaliteleri üzerine olan etkilerinin ölçülmesi amaçlandı.

\section{Gereç ve Yöntem}

Çalışmamıza, Temmuz 2009 ve Aralık 2009 tarihleri arasında Eskişehir Osmangazi Üniversitesi Tıp Fakültesi Deri ve Zührevi Hastalıkları Anabilim Dalı polikliniklerine başvuran, 16-30 yaş aralığında ve orta şiddetli aknesi olan 60 hasta dahil edildi. Çalışma için 30.06.2009 tarih ve 3 sayılı kararla etik kurul onayı alındı. Hastalar çalışma hakkında bilgilendirildi ve katılım için yazılı onayları alındı. Hastaların yaşı, cinsiyeti, hastalık süresi ve daha önce aldıkları tedaviler sorgulanarak kaydedildi.

Hastaların Çalışmaya Alınma Kriterleri:

- 16 yaş ve üzerinde olması

- Son 6 aydır sistemik retinoid tedavisi almamış olması

- Son 3 aydır oral kontraseptif kullanmıyor olması

- Son 1 aydır sistemik antibiyotik veya kortikosteroid kullanmamış olması

- Son 2 hafta içinde topikal akne preperatı kullanmamış olması

- 10 veya daha fazla papüler lezyon olması

Hastaların Çalışma Dışı Bırakılma Kriterleri:

- Akne kongloblata tanısı

- Akne fulminans tanısı

- Hastada üçten fazla nodüler lezyon olması

- Hastanın gebe, süt veren olması veya hastanın adet düzensizliği problemi

Hastalar iyi aydınlatılmış bir ortamda inspeksiyon ve palpasyon ile değerlendirildi. Tedavi öncesinde ve tedaviye başlandıktan sonraki 3 ay boyunca, her ay hastaların akne şiddeti Allen-Smith derecelendirilmesine (bu derecelendirme 0, 2, 4, 6, 8 şeklinde yapılmaktadır) göre değerlendirildi4. Tedavi öncesi yapılan Grade 8 olarak sınıflanan vakalar şiddetli akne olduğu için çalışma dışı bırakıldı.
Tedavi öncesinde ve tedavi sonrasında hastalara yaşam kalitelerinin nasıl etkilendiğinin belirlenmesi amacıyla Akne Yaşam Kalite Ölçeği ve Skindeks-29 uygulandı. Akne Yaşam Kalite Ölçeği, Gupta ve ark. ${ }^{5}$ tarafından geliştirilen ve Demirçay ve ark. 6 tarafından Türkçe'ye uyarlanan akneye özel yaşam kalite ölçeğidir. Skindeks-29, Chren ve ark.7,8 tarafından geliştirilen ve Aksu ve ark. ${ }^{9}$ tarafından Türkçeye uyarlanan, dermatolojiye özel yaşam kalite ölçeğidir. Her iki ölçekte de yüksek skor yaşam kalitesinin olumsuz yönde etkilendiğini göstermektedir.

Hastaların tedavi öncesinde ve tedavi süresince her ay tam kan sayımı sonuçları, renal ve hepatik fonksiyonları değerlendirildi.

Hastalara çalışma süresince düzenli olarak güneş kremi kullanmaları önerildi. Hastalar, kimyasal peeling yaptırmamaları, kozmetik amaçlı cilt bakım ürünleri kullanmamaları konusunda uyarıldı. Kadın hastalara gebe kalmamaları ve oral kontraseptifler dışında etkili bir doğum kontrol yöntemi kullanmaları önerildi.

Bu çalışmaya orta şiddetli akne vulgarisi olan 60 hasta alındı. Hastalar randomize olarak iki gruba ayrıldı. Birinci gruba haftada üç gün (aç karına) azitromisin 500 mg, ikinci gruba günlük doksisiklin 100 mg tedavisi verildi. Sistemik tedaviye ek olarak, her iki gruptaki hastaların tedavisine topikal adapalen jel eklendi. Adapalen jelin kuru deriye ince bir tabaka halinde akşamları uygulanması önerildi. Hastalar tedavi başlangı ından itibaren üç ay boyunca her ay takip edildi. Tedavi sonunda hastaların tedaviye verdiği yanıt Allen-Smith derecelendirilmesine ve inflamatuvar lezyonların global yanıtına göre değerlendirildi. Inflamatuvar lezyonların global yanıtına göre; lezyonlarda \%80 veya daha fazla azalma 'iyi yanıt', \%50-79 'orta yanıt', \%49-20 'kötü yanıt', \%20'den daha az yanıt 'yanıt yok' olarak değerlendirildi. Hastalar her kontrolde ilaçlara bağlı sistemik yan etkiler (diare, bulantı, karın ağrısı, çarpıntı, anjina, dispepsi, kusma, sarılık, vajinal kandidiyazis, anjioödem, fotosensitivite) ve lokal yan etkiler (eritem, pullanma, yanma ve kuruluk) açısından değerlendirildi. Lokal yan etkiler 'yok', 'hafif', 'orta' ve 'şiddetli' olarak değerlendirildi.

İstatistiksel analiz için SPSS-15 paket programı kullanıldı. İstatistiksel analizde Ki-kare testi, Student-t testi ve Spearmen korelasyon testi kullanıldı.

\section{Bulgular}

Çalışma orta şiddetli akne vulgarisi olan 60 hasta ile yapıldı. Çalışma grubunu oluşturan hastaların 20'si (\%33,3) erkek, 40'ı $(\% 66,7)$

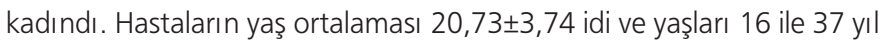
arasında değişmekteydi. Hastalık süresi 1 ile 15 yıl arasında olup, ortalama 5,03 $\pm 3,78$ yıldı. 
iki tedavi grubu arasında yaş, cinsiyet ve hastalık şiddeti açısından istatistiksel olarak anlamlı bir fark saptanmadı (p>0,05) (Tablo 1).

Tedavi öncesi ve tedavinin üçüncü ayında hastaların Allen-Smith Derecelendirmesi karşılaştırıldığında, tedavi sonrasında tedavi öncesine göre istatistiksel olarak anlamlı bir şekilde akne şiddetinin azaldığı bulundu ( $p<0,001)$ (Tablo 2).

Tedavi sonrasında her iki grupta da \%50'den fazla düzelme gözlendi. Lezyonların azalma yüzdesinde her iki tedavi arasında istatistiksel olarak anlamlı fark bulunamadı ( $p>0,05)$ (Tablo 3).

Azitromisin ile adapalen tedavisi alan bir hastada eritem, pullanma, yanma ve kuruluk yan etkileri şiddetli olarak görüldüğünden dolayı 1. ayın sonunda topikal adapalen jel tedavisi kesildi.

Topikal adapalen jel tedavisi alan hastalarda eritem, pullanma, yanma ve kuruluk yan etkilerinin 0. 1. 2. ve 3. aylardaki şiddeti Şekil 1'de gösterilmiştir. Tedavi sonrası birinci ayda, doksisiklin grubunda 3 hastada bulantı, 1 hastada ishal ve karın ağrısı, azitromisin grubunda ise 2 hastada bulantı gözlendi. Bu yan etkiler hafif şiddetli olup tedavinin birinci ayında saptandı. Tedavinin ikinci ve üçüncü aylarında yan etkiler geriledi.

Tedavinin ilk ayı sonrasında her iki tedavi rejimi arasında sistemik yan etkiler açısından anlamlı bir fark bulunamadı $(p>0,05)$.

Her iki çalışma grubunda tedavi öncesi Akne Yaşam Kalite Ölçeği ve Skindeks-29'un skorları ile akne şiddeti arasındaki ilişki Spearman

\begin{tabular}{|c|c|c|}
\hline Değişkenler & $\begin{array}{l}\text { Azitromisin } \\
+ \\
\text { Adapalen } \\
\mathrm{n}(\%)\end{array}$ & $\begin{array}{c}\text { Doksisiklin } \\
+ \\
\text { Adapalen } \\
\text { n (\%) }\end{array}$ \\
\hline $\begin{array}{l}\text { Cins } \\
\text { Erkek } \\
\text { Kadın }\end{array}$ & $\begin{array}{c}11(36,7) \\
19(63,3) \\
\chi^{2}: 0,300 ; p: 0,584\end{array}$ & $\begin{array}{c}9(\% 30) \\
21(\% 70)\end{array}$ \\
\hline $\begin{array}{c}\text { Yaş grubu (yıl) } \\
16-19 \\
20-37\end{array}$ & 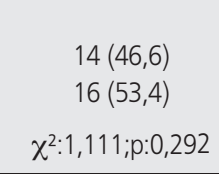 & $\begin{array}{l}10(33,3) \\
20(66,7)\end{array}$ \\
\hline $\begin{array}{c}\text { Akne derecesi } \\
\text { Grade } 4 \\
\text { Grade } 6\end{array}$ & $\begin{array}{r}22(73,3) \\
8(26,7) \\
\chi^{2}: 0,278 ; p: 0,095\end{array}$ & $\begin{array}{r}27(90) \\
3(10)\end{array}$ \\
\hline
\end{tabular}

Tablo 2. Allen - Smith Derecelendirmesinin tedavi öncesi ve sonrası dağılımı

\begin{tabular}{|l|c|c|}
\hline $\begin{array}{l}\text { Allen-Smith } \\
\text { Derecelendirme }\end{array}$ & $\begin{array}{c}\text { Tedavi öncesi } \\
\mathbf{n}(\%)\end{array}$ & $\begin{array}{c}\text { Tedavi sonrası } \\
\mathbf{n}(\%)\end{array}$ \\
\hline Grade 0 & $0(\% 0,0)$ & $44(100,0)$ \\
\hline Grade 2 & $0(\% 0,0)$ & $16(100,0)$ \\
\hline Grade 4 & $49(100,0)$ & $0(\% 0,0)$ \\
\hline Grade 6 & $11(100,0)$ & $0(\% 0,0)$ \\
\hline$\chi^{2}: 120.000 ; p: 0.000$ & \\
\hline
\end{tabular}

korelasyonu ile değerlendirildi. İstatistiksel olarak anlamlı ilişki saptanamadı (her biri için $p>0,05$ ).

Hastaların yaşam kalitesinde, tedavi sonrasında tedavi öncesine göre düzelme saptandı $(p<0,001)$.

Akne Yaşam Kalite Ölçeğinden elde edilen toplam skor ortalaması tedavi öncesinde $(15,15 \pm 4,82)$ tedavi sonrasına $(12,20 \pm 3,50)$ göre daha yüksek bulundu (Student-t testi) ( $t=3,834 ; 0,000)$. Tedavi sonrasında, Akne Yaşam Kalitesi ölçeğinden elde edilen toplam skor ortalaması, azitromisin ve adapalen tedavi rejiminde $11,83 \pm 3,12$, doksisiklin ve adapalen tedavi rejiminde $12,57 \pm 3,87 \mathrm{idi}$. Her iki tedavi rejimi uygulanan hasta grupları arasında toplam skor ortalamaları açısından anlamlı bir fark bulunamadı $(t=0,809 ; p=0,422)$.

Skindeks-29'un semptom, emosyon ve fonksiyon skalalarında tedavi sonrasında yaşam kalitesinde düzelme saptandı $(p<0,001)$ (Tablo 4). Tedavi sonrasında, her iki tedavi rejimi uygulanan hasta grupları arasında Skindeks-29'un semptom, emosyon ve fonksiyon skor ortalamaları açısından anlamlı bir fark bulunamadı ( $p>0,05)$ (Tablo 5).

Tablo 3. Tedavi sonrasında azitromisin ile adapalen ve doksisiklin ile adapalenin akne derecelerinin karşılaştırıması

\begin{tabular}{|l|c|c|}
$\begin{array}{l}\text { Allen-Smith } \\
\text { Derecelendirme }\end{array}$ & $\begin{array}{c}\text { Azitromisin+Adapalen } \\
\mathbf{n}(\%)\end{array}$ & $\begin{array}{c}\text { Doksisiklin+Adapalen } \\
\mathbf{n}(\%)\end{array}$ \\
\hline Grade 0 & $21(70)$ & $23(76,6)$ \\
\hline Grade 2 & $9(30)$ & $7(23,4)$ \\
\hline$\chi^{2}: 0,341 ; p: 0,559$ &
\end{tabular}

Tablo 4. Skindeks-29'un semptom, emosyon ve fonksiyon skalalarının skor ortalamalarının tedavi öncesi ve tedavi sonrasına göre dağılımı

\begin{tabular}{|l|c|c|r|}
\hline \multirow{2}{*}{$\begin{array}{l}\text { Skindeks Yaşam } \\
\text { Kalitesi Ölçeğinin } \\
\text { Skalaları }\end{array}$} & \multicolumn{2}{|c|}{$\begin{array}{c}\text { Tedavi Öncesi ve Sonrası Skor } \\
\text { Ortalamaları }\end{array}$} & \multirow{2}{*}{ ístatistiksel analiz } \\
\cline { 2 - 3 } & Tedavi Öncesi $\mathbf{p}$ & Tedavi Sonrası & \\
\hline Semptom & $39,58 \pm 18,57$ & $22,08 \pm 15,36$ & 5,$626 ; 0,000$ \\
\hline Emosyon & $44,50 \pm 17,86$ & $26,88 \pm 17,23$ & 5,$501 ; 0,000$ \\
\hline Fonksiyon & $22,50 \pm 16,99$ & $12,05 \pm 13,65$ & 3,$714 ; 0,000$ \\
\hline Student-t testi & & \\
\hline
\end{tabular}

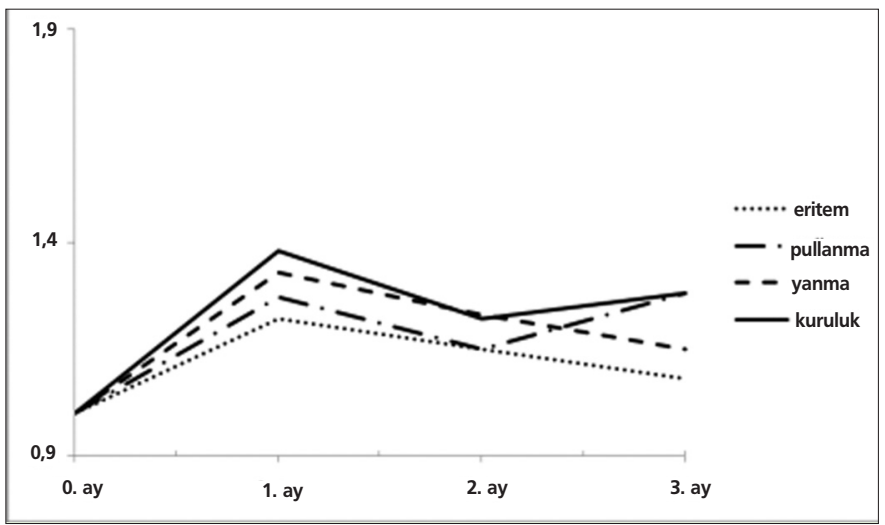

Şekil 1. Topikal adapalen jel tedavisi alan hastalarda eritemin, pullanma, yanma ve kuruluğun $0,1,2$, ve 3 . aylardaki şiddeti 
Tablo 5. İki tedavi rejimi için tedavi sonrası Skindeks-29'un semptom, emosyon ve fonksiyon skala ortalamalarının karşılaştııılması

\begin{tabular}{|l|c|c|c|}
\hline \multirow{2}{*}{$\begin{array}{l}\text { Skindeks-29 Yaşam } \\
\text { Kalitesi Ölçeğinin Skalaları }\end{array}$} & \multicolumn{2}{|c|}{$\begin{array}{c}\text { Yaşam Kalitesi Ölçekleri } \\
\text { Skor Ortalamaları (X } \pm \text { sd) }\end{array}$} & $\begin{array}{c}\text { istatistiksel analiz } \\
\text { t; } \mathbf{p}\end{array}$ \\
\cline { 2 - 4 } & $\begin{array}{c}\text { Azitromisin+Adapalen } \\
\text { Rejimi }\end{array}$ & $24,28 \pm 14,42$ & 1,$113 ; 0,270$ \\
\hline Semptom & $19,88 \pm 16,18$ & $29,08 \pm 16,71$ & 0,$993 ; 0,325$ \\
\hline Emosyon & $24,67 \pm 17,75$ & $12,36 \pm 13,21$ & 0,$176 ; 0,861$ \\
\hline Fonksiyon & $11,73 \pm 14,29$ & \\
\hline Student-t testi & & \\
\hline
\end{tabular}

\section{Tartışma}

Akne tedavisinin seçimi büyük ölçüde hastalığın şiddetine ve derecesine bağlıdır. Sistemik antibiyotikler orta ve şiddetli derecede inflamatuvar aknede, topikal antibiyotik tedavisinin yetersiz olduğu ya da kişinin tolere edemediği durumlarda, omuz, gövde, sırt gibi topikal ilaçları uygulamanın güç olduğu durumlarda, skarlaşma ya da pigment değişikliklerine eğilimi olan hafif ile orta şiddette olgularda endikedir10. Oral antibiyotiklerden birisi olan azitromisin ilk azalid antibiyotiktir. Duyarlı mikroorganizmaların 50S ribozomal subunitine bağlanarak protein sentezini engeller11,12. Azitromisin farklı çalışmalarda farklı şekillerde ${ }^{13-15}$ kullanılmış olmakla birlikte en sık görülen uygulama şekli haftada 3 kez 500 mg dozunda kullanımıdır16-18

Kapadia ve ark. ${ }^{17}$ inflamatuvar aknesi olan 35 hasta ile yaptıkları çalışmada, 12 hafta boyunca \%0,5 tretinoin ile birlikte azitromisin haftada 3 kez 500 mg dozunda uygulamışlar, çalışmanın sonunda inflamatuvar akne lezyonlarında \%80'e yakın düzelme saptamışlardır. Innocenzi ve ark. ${ }^{16}$ orta şiddette inflamatuvar aknesi olan 57 hastaya, topikal adapalen \%0,1 jel ya da krem ve benzoil peroksit jel ile birlikte azitromisin, haftada 3 kez 500 mg dozunda uygulamıştır. Oniki hafta sonunda azitromisin tedavisinin etkili ve güvenli olduğu ve hastalarının uyumunun iyi olduğu gösterilmiştir.

Bardazzi ve ark. ${ }^{18}$ yaptıkları çalışmada orta ve şiddetli papülopüstüler aknesi olan 52 hastaya 8 hafta boyunca azitromisin haftada 3 kez 500 mg dozunda kullanmıştır. Çalışma sonucunda azitromisinin adölesanlarda bile minimal yan etki ve iyi uyum ile etkili, güvenli ve tolere edilebilir bir ajan olduğu gösterilmiştir.

Bu çalışmada 30 hastaya azitromisin haftada 3 kez 500 mg dozunda, 3 ay boyunca verildi. Azitromisin tedavisinin etkili, güvenli olduğu ve hastaların uyumunun iyi olduğu gösterildi.

Akne tedavisinde kullanılan sistemik antibiyotiklerden birisi olan doksisiklinin bakterilerdeki protein sentezini; 30 S bakteriyel ribozoma bağlanarak ve aminoaçil tRNA'nın mRNA-ribozom kompleksi üzerindeki alıcı bölgeye ulaşmasını engelleyerek inhibe ettiği düşünülmektedir19,20 .Doksisiklinin akne tedavisi için önerilen dozu 100 mg/gündür19. 200 $\mathrm{mg} / \mathrm{gün}$ dozunda öneren yayınlarda mevcuttur20. Subantimikrobial dozda kullanıldığında da (50 mg/gün) etkili olduğu gösterilmiştir22.

Skidmore ve ark. ${ }^{22}$ yaptıkları çalışmada orta şiddetli aknesi olan 26 hastaya 6 ay boyunca doksisiklin 25 mg günde 2 kez uygulamış, 25 kişiye ise plasebo vermiştir. Tedavi sonunda subantimikrobiyal doz doksisiklin alan grupta komedon, inflamatuvar ve noninflamatuvar lezyonlarda ve total inflamatuvar lezyonların sayısındaki azalma plasebo grubundan anlamlı derecede daha fazla bulunmuştur.
Thiboutot ve ark. ${ }^{23}$ şiddetli aknesi olan hastalarda yaptıkları çalışmada, oral doksisiklin kapsül 100 mg/gün ile adapalenin kombinasyon şeklinde kullanımının, oral doksisiklin kapsül 100 mg/gün tek başına kullanımına göre total, inflamatuvar ve noninflamatuvar lezyonları azaltmada daha üstün olduğunu göstermiştir $(p<0,05)$. Lezyonların total azalma yüzdesinin, oral doksisiklin kapsül ile adapalenin kombinasyon şeklinde kullanımında \%61,2, oral doksisiklinin tek başına kullanımında ise \%45,3 olduğu belirtilmiştir.

Bu çalışmada 30 hastaya doksisiklin 100 mg/gün dozunda, 3 ay boyunca verildi. Doksisiklin tedavisinin etkili, güvenli olduğu ve hastaların uyumunun iyi olduğu gösterildi.

Topikal tedavide kullanılan ajanlardan birisi de retinoidlerdir. Retinoid, akne tedavisinde komedolitik etkisi en yüksek olan ajandır. Retinoidler foliküler epitelin deskuamasyonunu normalleştirir, yeni mikrokomedonların yani prekürsör lezyonların oluşumunu önler. Böylece komedonların ve inflamatuvar akne lezyonlarının her ikisini de en aza indirir24. Topikal retinoid kullanımı, antibiyotiklere karşı direnç gelişimini azalttığı için antibiyotiklerle kombine kullanımı önerilmektedir25. Adapalen üçüncü nesil retinoiddir ve naftoik asit derivesidir. Topikal uygulamalarda tretinoinden daha az irritandır26.

Bu çalışmada, azitromisin tedavisi alan 30 hastaya ve doksisiklin tedavisi alan 30 hastaya 3 ay boyunca topikal adapalen jel tedavisi eklendi.

Parsad ve ark.15 orta şiddetli aknesi olan 60 hasta ile yaptıkları çalışmada, 12 hafta boyunca topikal \%0,05 tretinoin kreme ek olarak ayda 4 gün, günde 1 kez 500 mg azitromisin ile topikal \%0,05 tretinoin kremle birlikte günlük 100 mg doksisiklinin etkinliklerini karşılaştırmışlar ve aylık azitromisin kullanımını günlük doksisiklin uygulaması kadar etkili bulmuşlardır.

Singhi ve ark. ${ }^{14}$ orta ve şiddetli inflamatuvar aknesi olan 70 hasta ile yaptıkları çalışmada 12 hafta boyunca 1. gruba azitromisin 10 günlük sikluslarda, ardışık 3 gün, günde 500 mg kullanılmış, geri kalan 7 gün ilaç verilmemiştir. 2. gruba günde $100 \mathrm{mg}$ doksisiklin tedavisi verilmiştir. Tüm hastalara topikal eritromisin tedaviside uygulanmıştır. Doksisiklin ile tedavi edilen grupta \%63,74'lük bir iyileşmeye karşılık azitromisin ile tedavi edilen grupta $\% 77,26^{\prime}$ lık bir iyileşme gözlenmiş ve bu fark istatistiksel olarak anlamlı bulunmuştur $(p<0,01)$.

Bu çalışmada tedavi sonrasında her iki tedaviyi alan hastaların lezyonlarında da \%50'den fazla düzelme gözlendi. Azitromisin ile adapalen tedavisi alan 21 hastada ve doksisiklin ile adapalen tedavisi alan 23 hastada \%80 ve daha fazla düzelme gözlendi. Tedavi sonrasında her iki tedavi yöntemi ile akne dereceleri arasında istatistiksel olarak anlamlı fark bulunmadı $(p>0,05)$. 
Her iki grupta kullanılan ajanlar güvenli bulunmuştur. Bir hastada topikal adapelen jel tedavisi yan etki sebebi ile kesilmiştir. Bunun dışında olan yan etkiler (lokal, sistemik) hafif şiddetli olup tedavi kesilmesini gerektirmemiştir. Hastaların takiplerinde karaciğer ve renal fonksiyonlarında herhangi bir anormallik saptanmamıştır.

Akneli hastaların tedavisinde aknenin hastanın yaşam kalitesi üzerine etkileri de göz önünde tutulmalıdır. Bu çalışmada da saptandığı gibi aknenin şiddeti ile aknenin yaşam kalitesi üzerine etkisi her zaman ilişkili değildir. Yaşam kalite ölçeklerinin kullanılması, aknenin hastanın yaşantısı üzerine olan etkisini göstermede yol göstericidir.

Kronik ve sık görülen bir hastalık olan akne genellikle toplum tarafından fizyolojik bir olay olarak değerlendirilmekte ve normalize edilmektedir. Akne hayatı tehdit eden ciddi bir hastalık olmamasına rağmen, kişinin yaşam kalitesini önemli ölçüde etkileyebilmektedir.

Lasek ve ark.27 yaptıkları çalışmada, akne hastalarının yaşam kalitelerinin emosyonel alanda psoriasis hastaları kadar etkilendiğini göstermiştir. Aksu ve ark. 28 yaptığı çalışmada psoriasis, ekzema ve akne tanısı alan hastaların semptom, emosyon ve fonksiyon skala ortalamaları arasında istatistiksel olarak anlamlı fark saptamamış ve akne, ekzema ve psoriasisin yaşam kalitesine etkisinin benzer olduğu ve bu hastalıkların yaşam kalitesinin her üç alanını da etkilediğini belirtmişlerdir.

Sonuç olarak azitromisin ve adapalen ile karşılaştırılan doksisiklin ve adapalen rejimleri orta şiddetli akne vulgaris tedavisinde etkili ve güvenli bulunmuş, hastaların yaşam kalitesinde düzelme sağladığı saptanmıştır. Tedavi rejimlerinin etkinliği değerlendirildiğinde, akne şiddeti ve yaşam kalitesi üzerine olan etki açısından iki tedavi rejimi arasında fark saptanmamıştır.

\section{Kaynaklar}

1. Acar MA, Günaştı $S$, Aksungur VL: Akne ve Benzeri Hastalıklar. Dermatoloji. Ed. Tüzün Y, Gürer MA, Serdaroğlu S, Oğuz O, Aksungur VL. 3. Baskı. İstanbul, Nobel Tıp Kitabevleri, 2008;1189-216.

2. Ermertcan AT: Akne ve yaşam kalitesi. Dermatose 2007;6:91-7.

3. Krautheim A, Gollnick HP: Acne: Topical treatment. Clin Dermatol 2004;22:398-407.

4. Allen BS, Smith JG: Various parameters for grading acne vulgaris. Arch Dermatol 1982;118:23-5.

5. Gupta MA, Johnson AM, Gupta AK: The development of an acne quality of life scale: reliability, validity and relation to subjective acne severity in mild to moderate acne vulgaris. Acta Derm Venerol 1998;78:451-6.

6. Demirçay Z, Şenol A, Seçkin D, Demir F: Akne vulgarisli hastalarda akne yaşam kalite ölçeğinin Türkçe güvenilirlik çalışması. Türkderm 2006;40:94-7.

7. Chren MM, Lasek RJ, Quinn LM, Mostow EN, Zyzanski SJ: Skindex, a quality-of-life measure for patients with skin disease: reliability, validity, and responsiveness. J Invest Dermatol 1996;107:703-13.
8. Chren MM, Lasek RJ, Flocke SA, Zyzanski SJ: Improved discriminative and evaluative capability of a refined, Version of Skindex, a quality-of-life instrument for patients with skin diseases. Arch Dermatol 1997; 133:1433-40.

9. Aksu $A E$, Ürer MS, Sabuncu I, Saraçoğlu ZN, Chren MM: Turkish version of Skindex-29. Int J Dermatol 2007;46:350-5.

10. Brown SK, Shalita AR: Acne vulgaris. The Lancet 1998;351:1871-76.

11. Özkan AŞ, Alper S: Sistemik tedavi. Dermatoloji. Ed. Tüzün Y, Gürer MA, Serdaroğlu S, Oğuz O, Aksungur VL. 3. Baskı. İstanbul, Nobel Tıp Kitabevleri, 2008;2147-77.

12. Gasbarre CC, Schmitt SK, Tomecki KJ: Systemic therapy. Fitzpatrick's Dermatology in General Medicine. Ed. Wolff K, Goldsmith LA, Katz SI, GIlchrest BA, Paller AS, Leffell DJ. 7th edition. New York, Mc Graw-Hill Inc, 2008;2194-203.

13. Fernandez- Obregon AC: Azithromycin for the treatment of acne. Int J Dermatol 2000;39:45-50

14. Singhi MK, Ghiya BC, Dhabhai RK: Comparison of oral azithromycin pulse with daily doxycycline in the treatment of acne vulgaris. Indian J Dermatol Venerol Leprol 2003;69:274-6.

15. Parsad D, Pandhi R, Nagpal R, Negi KS: Azithromycin monthly pulse vs daily doxycycline in the treatment of acne vulgaris. Int J Dermatol 2000;39:45-50

16. Innocenzi D, Skroza N, Ruggiero A, Concetta Potenza M, Kensun Proietti I: Moderate acne vulgaris: efficacy, tolerance and compliance of oral azithromycin thrice weekly for. Acta Dermatovenerol Croat 2008;16:13-8.

17. Kapadia N, Talib E: Acne treated successfully with azithromycin. Int J Dermatol 2004;43:766-7.

18. Bardazzi F, Savoia F, Parente G, et al: Azitromycin: a new therapeutical strategy for acne in adolescents. Dermatol Online J 2007;13:4.

19. Tsankov N, Broshtilova V, Kazandjieva J: Tetracyclines in dermatology. Clin Dermatol 2003;21:33-9.

20. Amichai B, Grunwald MH: Tetracyclines in dermatology. J Dermatolog Treat 1999;8:15-23.

21. Nelson AM, Thiboutot DM: Disorders of the sebaceous glands. Fitzpatrick's Dermatology in General Medicine. Ed. Wolff K, Goldsmith LA, Katz SI, GIIchrest BA, Paller AS, Leffell DJ. 7th edition. New York, Mc Graw-Hill Inc, 2008;687-703.

22. Skidmore $R$, Kovach $R$, Walker $C$, et al: Effects of subantimicrobial-dose doxycycline in the treatment of moderate acne. Arch Dermatol 2003;139:459-64.

23. Thiboutot DM, Shalita AR, Yamauchi PS, et al: Differin Study Group. Combination therapy with adapalene gel $0.1 \%$ and doxycycline for severe acne vulgaris: A multicenter, investigator-blind, randomized, controlled study. Skinmed 2005;4:138-46.

24. Leyden JJ: A review of the use of combination therapies for the treatment of acne vulgaris. J Am Acad Dermatol 2003;49:200-10.

25. Katsambas AD, Stefanaki C, Cunliffe WJ: Guidelines for treating acne. Clin Dermatol 2004;22:439-44.

26. Irby CE, Yentzer BA, Feldman SR: A review of adapalene in the treatment of acne vulgaris. J Adolesc Health 2008;43:421-4.

27. Lasek RJ, Chren MM: Acne vulgaris and the quality of life of adult dermatology patients. Arch Dermatol 1998;134:454-8.

28. Aksu AE, Saraçoğlu ZN, Sabuncu i: Akne, ekzema ve psoriasisli hastalarda yaşam kalitesi. Osmangazi Tıp Dergisi 2007;29:119-30. 